\title{
SP-A Binding Sites on Bovine Alveolar Macrophages
}

\author{
Sandra Plaga, Helmut Plattner, and Jutta Schlepper-Schaefer ${ }^{1}$ \\ Department of Biology, University of Konstanz, D-78434 Konstanz, Germany
}

\begin{abstract}
Surfactant protein A (SP-A) binding to bovine alveolar macrophages was examined in order to characterize SP-A binding proteins on the cell surface and to isolate putative receptors from these cells that could be obtained in large amounts. Human SP-A, unlabeled or labeled with gold particles, was bound to freshly isolated macrophages and analyzed with ELISA or the transmission electron microscope. Binding of SP-A was inhibited by $\mathrm{Ca}^{2+}$ chelation, by an excess of unlabeled SP-A, or by the presence of $20 \mathrm{mg} / \mathrm{ml}$ mannan. We conclude that bovine alveolar macrophages expose binding sites for SP.A that are specific and that depend on $\mathrm{Ca}^{2+}$ and on mannose residues. For isolation of SP-A receptors with homologous SP-A as ligand we isolated SP-A from bovine lung lavage. SDS-PAGE analysis of the purified SP.A showed a protein of $32-36 \mathrm{kDa}$. Functional integrity of the protein was demonstrated. Bovine SP-A bound to Dynabeads was used to isolate SP-A binding proteins. From the fractionated and blotted proteins of the receptor preparation two proteins bound SP-A in a $\mathrm{Ca}^{2+}$-dependent manner, a 40-kDa protein showing mannose dependency and a 210-kDa protein, showing no mannose sensitivity. - 1998 Academic Press
\end{abstract}

Key Words: surfactant protein A; SP-A receptors; bovine alveolar macrophages; mannose-dependent binding; lung.

\section{INTRODUCTION}

Surfactant protein A (SP-A), ${ }^{2}$ the main protein component of the lung surfactant, is a multifunctional protein. This is reflected in the structure of the protein which reveals several different domains (for review, see [1]). This structure enables SP-A to bind to different surfaces and substances, thereby achiev-

\footnotetext{
${ }^{1}$ To whom reprint requests should be addressed. Fax: 49 (7531) 882245. E-mail: Jutta.Schlepper-Schaefer@uni-Konstanz.de.

${ }^{2}$ Abbreviations used: BSA, bovine serum albumin; ELISA, enzyme-linked immunosorbent assay; HSS, Hank's balanced salt solution; PBS, phosphate-buffered saline; SP-A, surfactant protein A; CRD, carbohydrate recognition domain; FCS, fetal calf serum; POX, peroxidase; RT, room temperature; $\mathrm{CRF}$, collagenase-resistant fragment.
}

ing different effects. Specific binding to cells of the respiratory tract has been described as well as binding to carbohydrates, phospholipids, lipopolysaccharide, and the surface of microorganisms (for review, see [2]). Binding to type II cells and to alveolar macrophages have been especially examined, since the central effects of SP-A on lung function include interaction with these cells. For instance, the regulatory function of the SP-A on the pathway of lung surfactant requires interaction with type II cells (for review, see [3]). The binding to type II cells is specific and of high affinity $[4,5]$. Involvement of the carbohydrate recognition domain (CRD) in binding was found by Kuroki et al. [6]. The intact collagen-like domain also appears necessary for function [7].

The role of SP-A in lung defence requires binding to alveolar macrophages. We have previously described SP-A binding to be mannose- and $\mathrm{Ca}^{2+}$-dependent and concluded that binding occurs via the CRD [8, 9]. On the other hand, Pison et al. [10] found binding via the collagen-like domain. This is in agreement with Malhotra et al. [11, 12], who described binding of SP-A to the $\mathrm{C} 1 \mathrm{q}$ receptor. Recently, Chroneos et al. [13] isolated a 210-kDa protein localized on macrophages and type II cells that seemed to bind the collagen-like tail of SP-A. Moreover, they demonstrated that binding of SP-A to macrophages was distinct from binding to the $\mathrm{C} 1 \mathrm{q}$ receptor. Taken together, it seems possible that alveolar macrophages and also type II cells expose more than one type of receptor for SP-A, in agreement with its different functions.

We now have characterized the binding of SP-A to bovine alveolar macrophages and have isolated SP-A binding proteins with the use of homologous SP-A. We describe two putative $\mathrm{SP}-\mathrm{A}$ receptors, a $40-\mathrm{kDa}$ protein that binds SP-A in a $\mathrm{Ca}^{2+}$-dependent and mannoseinhibitable manner and a $210-\mathrm{kDa}$ protein that binds SP-A in a $\mathrm{Ca}^{2+}$-dependent but mannose-insensitive way. The latter protein may be identical with that described by Chroneos et al. [13]. Isolation was from bovine alveolar macrophages, because one can get large amounts of cell materials by using the homologous bovine SP-A as ligand. 


\section{MATERIALS AND METHODS}

\section{Materials}

Human SP-A isolated from lung lavage of proteinosis patients as described [14] was a gift from Dr. Klaus P. Schäfer (Byk Gulden Pharmaceuticals, Department of Molecular Biology, Konstanz, Germany).

Fluorescein isothiocyanate was from Molecular Probes (Eugen, OR). Bovine serum albumin (BSA) and bovine serum were from Sigma (München, Germany). Actin from bovine muscle was from Fluka (Buchs, Switzerland). Rabbit antibodies against human muscle actin, against myosin heavy chain from rabbit muscle, and against bovine muscle myosin were from Sigma. Antiserum against bovine SP-A was produced in rabbits and its specificity was tested by enzyme-linked immunosorbent assay (ELISA) and with blotted SP-A. Antiserum against human SP-A was a gift from Dr. Klaus P. Schäfer.

\section{Cells}

Bovine alveolar macrophages were isolated by lung lavage from bovine lung. Lavage was performed with phosphate-buffered saline $\left(\mathrm{Ca}^{2+}\right.$ - and $\mathrm{Mg}^{2+}$-free, PBS from Gibco, Eggenstein, Germany) containing $5 \%$ fetal calf serum (FCS from Boehringer, Mannheim, Germany) and $1.5 \mathrm{mM}$ EDTA at $37^{\circ} \mathrm{C}$. Lavage fluid was centrifuged at $240 \mathrm{~g}$ for $10 \mathrm{~min}$. Cells were washed twice with Hank's balanced salt

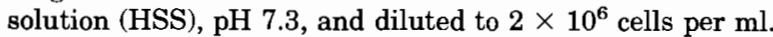

\section{Characterization of Bovine Alveolar Macrophages}

Bovine alveolar macrophages freshly isolated from bovine lung lavage were vital as proved by trypan blue exclusion ( $>95 \%)$. They reacted positive in color tests for esterase. The proportion of other cells in the macrophage preparation varied and included erythrocytes and some ciliated cells of the conducting airways. We used only preparations with more than $70 \%$ macrophages. In the electron microscope macrophages exhibited the typical appearance of cell organelles. Compared to rat alveolar macrophages the amount of different phagosomes per cell section was higher. The phagosomes contained surfactant, cell debris, and very few microorganisms. The physiological functioning of the macrophages was indicated by serum-dependent enhancement of phagocytosis of Staphylococcus aureus. The interaction of the macrophages with bacteria was monitored as described previously [15].

\section{Binding of SP-A to Bovine Alveolar Macrophages}

Transmission electron microscopy. SP-A was adsorbed onto colloidal gold particles of $17 \mathrm{~nm}$ as described previously [16, 17]. Macrophages $\left(2 \times 10^{6}\right.$ cells in $240 \mu$ l HSS $)$ were mixed with gold-labeled SP-A and incubated for $10 \mathrm{~min}$ at $37^{\circ} \mathrm{C}$. For inhibition, cells were preincubated with unlabeled SP-A $(40 \mu \mathrm{g} / \mathrm{ml})$ or with $10 \mathrm{mM}$ EDTA for $2 \mathrm{~min}$ at $37^{\circ} \mathrm{C}$ before adding gold-labeled SP-A. Cells were prepared for ultrathin sectioning and electron microscopy as described previously [9]. Gold particles associated with median sections of macrophages of $100 \mathrm{~nm}$ (pale gold interference color) were counted.

ELISA. Quantitative estimation of SP-A binding to macrophages was also determined by ELISA. Macrophages $\left(10^{4}\right.$ per well) were immobilized on microtiter wells for $1 \mathrm{~h}$ at $37^{\circ} \mathrm{C}$, washed three times, and then incubated with different concentrations of SP-A for $5 \mathrm{~min}$ at $37^{\circ} \mathrm{C}$, with or without addition of inhibitors. After blocking nonspecific binding with 5\% FCS in PBS bound SP-A was detected by addition of $100 \mu \mathrm{l}$ anti-SP-A serum diluted 1:2000 in 1\% FCS/PBS (2 $\mathrm{h}$ on ice), followed by three washes and incubation with $100 \mu \mathrm{l}$ anti-rabbit IgG labeled with peroxidase (POX), diluted 1:20,000 in $1 \% \mathrm{FCS} / \mathrm{PBS}$ ( $2 \mathrm{~h}$ on ice). After another three washes $100 \mu \mathrm{l}$ of a substrate solution containing 1,2-o-phenylenediamine (Sigma) was added to each well. The color was allowed to develop for 5-10 min and was registered with a microtiter plate reader. Unspecific SP-A binding to the plate was determined with wells without macrophages and this background was substrated. Additional controls consisted of wells with macrophages but lacking SP-A to estimate binding of the primary and secondary antibodies to the cells. These ELISA readings were also subtracted from those obtained for test wells to obtain the net readings that reflect binding of SP-A to the immobilized cells.

We also used ELISA to estimate specific antibodies in the serum which we produced in rabbits. Bovine SP-A at $50 \mathrm{ng}$ per well were incubated overnight at room temperature (RT) to immobilize the protein. After washing the wells three times with PBS, unspecific binding was blocked by $5 \%$ FCS for $2 \mathrm{~h}$. Different dilutions of the serum were incubated in $1 \%$ FCS/PBS for $1 \mathrm{~h}$ at RT. Bound antibodies were recorded with anti-rabbit IgG-POX after washing (see above).

\section{Isolation of SP-A from Bovine Lung Lavage}

SP-A was isolated from bovine surfactant obtained as described by Hawgood et al. [18] including precipitation by butanol [14]. To inhibit proteases we added $50 \mu \mathrm{g} / \mathrm{ml}$ Pefabloc, $1 \mathrm{mM}$ benzamidine (both from Serva, Heidelberg) and $0.2 \mathrm{mM}$ EGTA to the lavage.

\section{Binding of SP-A-Labeled Dynabeads}

Dynabeads (M-280, Dynal, Hamburg, Germany) were labeled with SP-A as described by Oosting and Wright [19]. Macrophages $\left(10^{5}\right)$ were mixed with $10^{6}$ Dynabeads in $100 \mu \mathrm{l} \mathrm{Hank's/Hepes,} \mathrm{centrifuged}$ for $10 \mathrm{~min}$ at $140 \mathrm{~g}$, and incubated for $1 \mathrm{~h}$ at $37^{\circ} \mathrm{C}$. For inhibition studies, EGTA or unlabeled SP-A was present throughout the incubation. Tests were evaluated by light microscopy.

\section{Isolation of the SP-A Receptor from Bovine Alveolar Macrophages}

Macrophages $\left(2 \times 10^{8}\right)$ were mixed with SP-A-labeled Dynabeads (1:10), centrifuged $\left(240 \mathrm{~g}, 10 \mathrm{~min}\right.$ ) and incubated for $1 \mathrm{~h}$ at $37^{\circ} \mathrm{C}$ and $5 \% \mathrm{CO}_{2}$. The cell pellet was lysed with $2 \%$ Triton X-100 in $0.2 \mathrm{M}$ $\mathrm{NaCl}, 20 \mathrm{mM}$ Tris/HCl, $\mathrm{pH} 7.4,2 \mathrm{mM} \mathrm{CaCl}_{2}, 10 \mu \mathrm{g} / \mathrm{ml}$ DNAse, $1 \mathrm{mM}$ $\mathrm{MgCl}_{2}$ [20], and protease inhibitors ( $1 \mathrm{mM}$ benzamidin, $50 \mu \mathrm{g} / \mathrm{ml}$ Pefabloc, $50 \mu \mathrm{g} / \mathrm{ml}$ Leupeptin, $10 \mu \mathrm{g} / \mathrm{ml}$ Pepstatin A, $100 \mu \mathrm{g} / \mathrm{ml}$ $p$-tosyl-L-arginin-methylester-hydrochloride (TAME) from Serva and $10 \mu \mathrm{l} / \mathrm{ml}$ Aprotinin from Sigma) for $2 \mathrm{~h}$ on ice. Dynabeads with the attached SP-A receptor complex were separated from the cell debris by magnetic force and further stirred on ice overnight to degrade DNA. After washing the beads, $10 \mathrm{mM}$ EDTA was added to detach the receptor from the SP-A Dynabeads. The supernatant was concentrated in Centrisart tubes (Sartorius, Göttingen, Germany) with a membrane excluding proteins of $>10,000 \mathrm{kDa}$

\section{SDS-PAGE and Protein Blotting}

SDS-PAGE was performed according to Laemmli [21] under reducing conditions. Ten percent polyacrylamide or 5-15\% gradient gels were used. Samples, except receptor preparations, were heated to $96^{\circ} \mathrm{C}$ in SDS-PAGE buffer for 2 min. Proteins were blotted onto nitrocellulose in a transfer buffer containing $25 \mathrm{mM}$ Tris, $192 \mathrm{mM}$ glycine, $20 \%$ methanol, pH 8.25 .

Blots were incubated with $5 \% \mathrm{BSA}$ in $25 \mathrm{mM}$ Tris, $146 \mathrm{mM} \mathrm{NaCl}$, $0.1 \%$ Tween, $1 \mathrm{mM} \mathrm{CaCl}$, $\mathrm{pH} 7.6$ (Tris buffer) to bloc unspecific binding. After washing $1 \mu \mathrm{g} / \mathrm{ml}$ bovine SP-A in Tris buffer was added to the blot for overnight incubation at $4^{\circ} \mathrm{C}$. For inhibition, $20 \mathrm{mg} / \mathrm{ml}$ mannan was added or Tris buffer without $\mathrm{Ca}^{2+}$ was used. Bound SP-A was detected by anti-bovine antiserum (1:3000) followed by incubation with anti-rabbit IgG antibody labeled with alkaline phosphatase (1:100). After washing, the blot was stained with Sigma Fast BCIP/NBT $(0.15 \mathrm{mg} / \mathrm{ml}$ 5-bromo-4-chloro-3-indolyl phosphate $p$-toluidine salt, $0.30 \mathrm{mg} / \mathrm{ml}$ nitro-blue tetrazolium, $5 \mathrm{mM} \mathrm{MgCl}$ in 100 $\mathrm{mM}$ Tris). Controls in the absence of SP-A were performed to exclude 
TABLE 1

Binding of Gold-Labeled SP-A to Bovine Alveolar Macrophages

\begin{tabular}{lccccc}
\hline & & $\begin{array}{c}\text { Gold particles } \\
\text { per cell } \\
\text { section } \\
( \pm \text { s.d. })\end{array}$ & $n$ & $\%$ Inhibition \\
Preincubation & Concentration & $52 \pm 27$ & 42 & - \\
\hline Buffer & - & $23 \pm 17$ & 18 & 56 \\
SP-A & $40 \mu \mathrm{g} / \mathrm{ml}$ & $8 \pm 8$ & 27 & 85 \\
EGTA & $10 \mathrm{mM}$ & \pm &
\end{tabular}

Note. Cells were preincubated with the inhibitors for 2 min at $37^{\circ} \mathrm{C}$. After addition of SP-A-coated gold particles, incubation was continued for $10 \mathrm{~min}$. Ultrathin sections $(100 \mathrm{~nm})$ were analyzed in the transmission electron microscope and the gold particles per cell section were counted. $n$, number of cell sections analyzed. s.d. standard deviation.

direct interaction of the primary and secondary antiserum with the protein bands.

For detection of SP-A, actin, or myosin, the blots were probed (after blocking of unspecific background) with anti-bovine SP-A antiserum (1:3000), anti-actin antiserum (1:100), and anti-myosin antiserum (1:100), respectively, and incubated with anti-rabbit IgG antibodies labeled with alkaline phosphatase (1:100). Staining was as described above.

\section{RESULTS}

\section{Characterization of SP-A Binding Sites on Bovine Alveolar Macrophages}

To localize and characterize the presumed SP-A binding proteins on bovine alveolar macrophages binding of SP-A to the cells was tested by electron microscopy and by ELISA.

SP-A-coated gold particles were bound and ingested following the coated pit/vesicle pathway (data not shown). Quantitative analysis revealed that binding and uptake was inhibited by an excess of unlabeled SP-A as well as by EGTA (Table 1). Hence, binding of SP-A is specific and depends on $\mathrm{Ca}^{2+}$ ions, and bovine cells show the same characteristics in binding and uptake of SP-A as we have previously described for rat alveolar macrophages [9].

To further establish SP-A receptors on bovine macrophages we tested binding of SP-A to immobilized cells by ELISA, showing that binding is saturable (Fig. 2A) and can be inhibited, at least partially, by mannan, a mannose polymer (Fig. 2C). A comparison with rat macrophages (Figs. 2B and 2D) shows the same characteristics.

\section{Bovine SP-A}

Analysis on SDS-PAGE gels proved considerable purification of the bovine SP-A (Fig. 1). Under reducing conditions, bovine SP-A showed a dominant band at

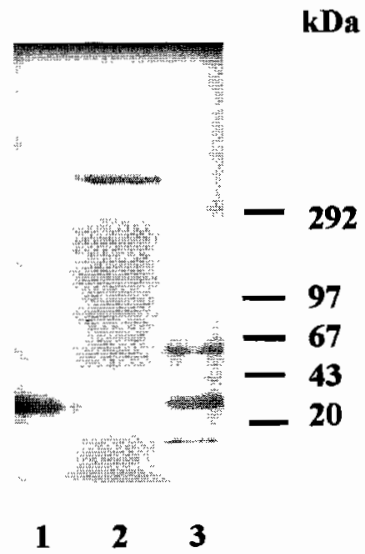

FIG. 1. Isolation of bovine SP-A. Purified bovine SP-A (lanes 1 and 2) was fractionated on a 10\% SDS-PAGE gel, stained with Coomassie blue, and compared with human SP-A from proteinosis patients (lane 3) under reducing (lanes 1 and 3 ) and nonreducing (lane 2) conditions.

$32-36 \mathrm{kDa}$ and a small band at $28 \mathrm{kDa}$ that represents the unglycosylated form (Fig. 1, lane 1). Under nonreducing conditions the multimeric form of SP-A was preserved (Fig. 1, lane 2). The functional integrity of
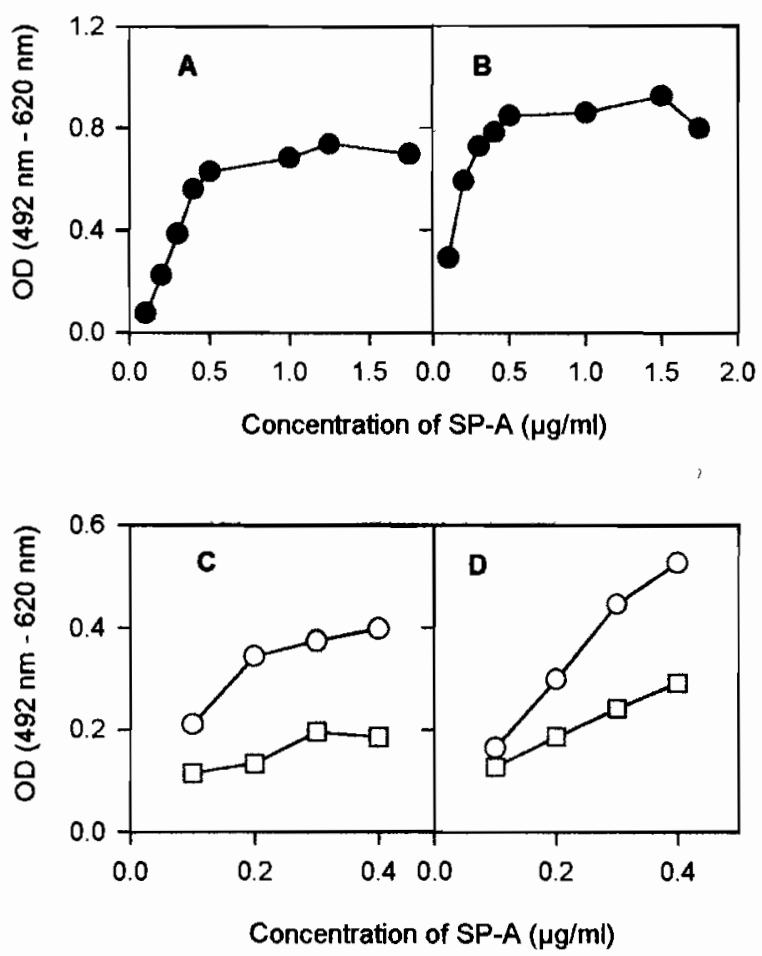

FIG. 2. Binding of SP-A to alveolar macrophages. (A, B) Bovine (A) and rat (B) macrophages immobilized on microtiter wells were incubated with different concentrations of human SP-A for $20 \mathrm{~min}$. Bound SP-A was determined by ELISA. (C, D) Bovine (C) and rat (D) macrophages were incubated with SP-A in the absence (circles) or presence of $20 \mathrm{mg} / \mathrm{ml}$ mannan (squares) for $5 \mathrm{~min}$. 


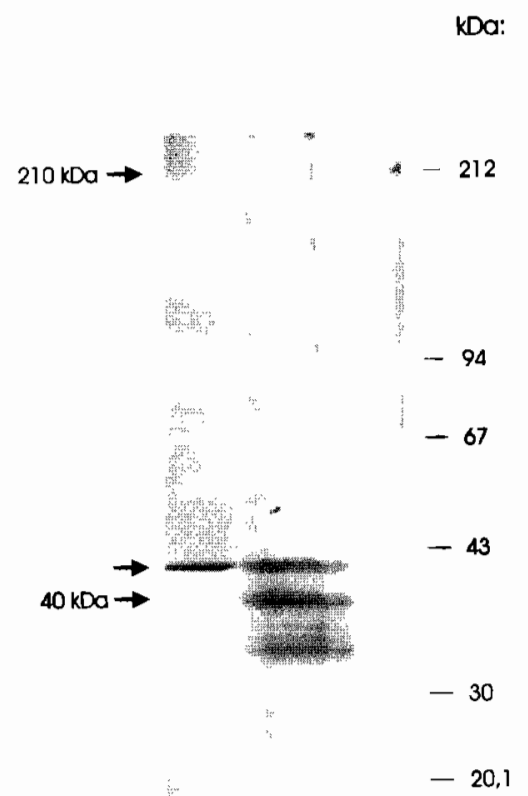

FIG. 3. Isolation of SP-A receptor from bovine alveolar macrophages. SP-A receptor preparation (lane 2) was fractionated on a 5-15\% SDS-PAGE gel under reducing conditions and compared to actin from bovine muscle (lane 1) and to myosin heavy chain from rabbit muscle (lane 3). Coomassie blue-stained gel.

isolated bovine SP-A was tested. The liposome aggregation assay according to Hawgood et al. [18] demonstrated the phospholipid binding and aggregation ability of the SP-A. Inhibition of PMA-stimulated surfactant secretion by the SP-A preparation was shown in the surfactant secretion assay described by Dobbs [22] with adherent type II cells. Furthermore, bovine SP-A stimulated phagocytosis of $S$. aureus by rat alveolar macrophages. All three functional tests, together with SDS-PAGE analysis, proved the quality of the SP-A preparation.

\section{Isolation of SP-A Receptors}

For isolation of SP-A receptors from bovine alveolar macrophages we used the bovine SP-A as homologous ligand. In principle, we bound SP-A-labeled Dynabeads to the macrophages in the presence of $\mathrm{Ca}^{2+}$, separated the ligand-receptor-Dynabead complex from the cells by treatment with Triton X-100 and by magnetic force, and detached the receptor from the ligand by $\mathrm{Ca}^{2+}$ depletion. Binding of SP-A-labeled Dynabeads to the macrophages was analyzed in the light microscope and was determined for each receptor preparation. $\mathrm{Ca}^{2+}$ dependency and specificity of the binding was proved by inhibition with EGTA and with unlabeled SP-A (data not shown).

The receptor preparation was concentrated and analyzed by SDS-PAGE. Silver staining revealed proteins of $210,43,40$, and $33 \mathrm{kDa}$ and still other bands
(Fig. 3, lane 2). For comparison, lane 1 shows actin from bovine muscle at $43 \mathrm{kDa}$ and lane 3 shows myosin heavy chain from rabbit muscle at $210 \mathrm{kDa}$.

The fractionated proteins from the receptor preparation were blotted onto nitrocellulose and incubated with SP-A (Fig. 4). In presence of $\mathrm{Ca}^{2+}$ (Fig. 4, lane 1) binding occurred to the $40-\mathrm{kDa}$ protein, to a $67-\mathrm{kDa}$ band, and to a broad protein band of $32-36 \mathrm{kDa}$. No binding was detected to the $43-\mathrm{kDa}$ protein (presumably actin). In the absence of $\mathrm{Ca}^{2+}$ binding only to the 40-kDa protein was inhibited (Fig. 4, lane 2). A comparison with blotted BSA (67 $\mathrm{kDa})$ and bovine SP-A (32-36 kDa) showed that SP-A bound to both these proteins in a $\mathrm{Ca}^{2+}$-independent manner (data not shown). Therefore, we conclude that the receptor preparation contained both BSA and SP-A due to the preparation procedure applied. When a higher protein concentration was used for electrophoresis and blotting, a $210-\mathrm{kDa}$ protein band was also visible and it bound SP-A intensely (Fig. 5A, lane 1). SP-A incubation of the blot without $\mathrm{Ca}^{2+}$ (Fig. 5A, lane 2) again substantially reduced binding to the $40-\mathrm{kDa}$ band and also to the $210-\mathrm{kDa}$ band, although to a lesser extent. Addition of mannan in the presence of $\mathrm{Ca}^{2+}$ visibly reduced SP-A binding to the $40-\mathrm{kDa}$ protein, while binding to the 210-kDa band seemed not to be effected (Fig. 5B, lane 2).

Because of the molecular weight we suspected that the $43-\mathrm{kDa}$ protein might be actin (see Fig. 3). Therefore, the fractionated proteins of the receptor preparation were blotted and incubated with antiserum against human muscle actin (Fig. 6, lane 2). The result showed prominent labeling of the $43-\mathrm{kDa}$ protein but only very slight labeling of the $40-\mathrm{kDa}$ protein, while incubation of the blot with SP-A (Fig. 6, lane 1) labeled

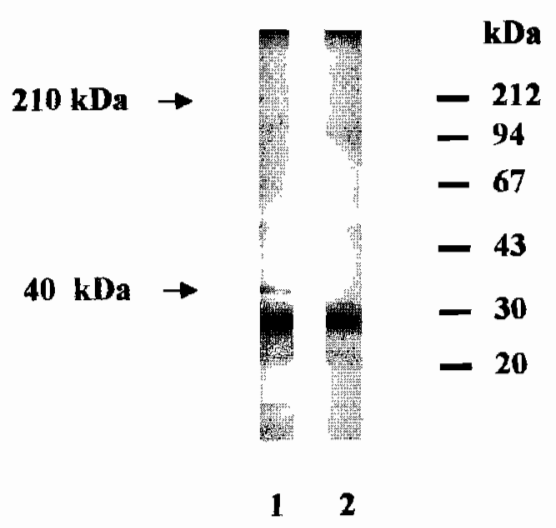

FIG. 4. Binding of SP-A to proteins from the receptor preparation. SP-A receptor preparation fractionated on 10\% SDS-PAGE under reducing conditions was blotted onto nitrocellulose and incubated overnight with bovine SP-A in the presence (lane 1) or the absence (lane 2) of $\mathrm{Ca}^{2+}$. Bound SP-A was detected with anti-bovine SP-A antiserum and an alkaline phosphatase-labeled second antibody. 
$\mathbf{A}$

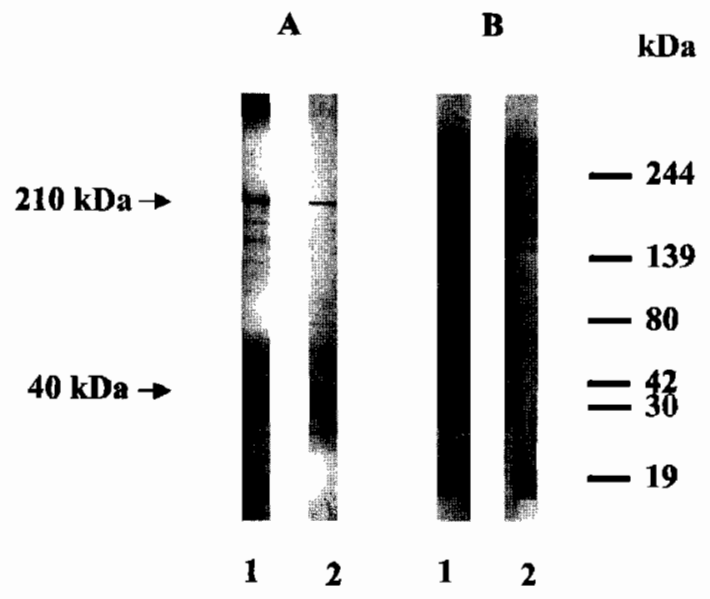

FIG. 5. Binding of SP-A to proteins from the receptor preparation. (A) Fractionated SP-A receptor preparation at threefold concentration as in Fig. 1 was blotted and incubated with SP-A with (lane 1) and without (lane 2) $\mathrm{Ca}^{2+}$. In addition to the $40-\mathrm{kDa}$ protein, a $210-\mathrm{kDa}$ protein is visible at higher protein concentrations. (B) Fractionated SP-A receptor preparation was blotted and incubated with SP-A with $\mathrm{Ca}^{2+}$ (lane 1) and additionally with $20 \mathrm{mg} / \mathrm{ml}$ mannan (lane 2).

the $40-\mathrm{kDa}$ protein but not the $43 \mathrm{kDa}$ protein, as already demonstrated. Conversely, actin from bovine muscle was also fractionated on the gel and blotted. It was labeled by antiserum against human muscle actin (Fig. 6, lane 3), but not by incubation with SP-A (not shown).

To characterize the $210-\mathrm{kDa}$ protein, possibly containing myosin (see Fig. 3), we also incubated the blot of the receptor preparation with antiserum against bovine muscle myosin, but we found no crossreaction (Fig. 6, lane 4), while myosin heavy chain from rabbit muscle was found at the same position on the blot (equivalent to a $210-\mathrm{kDa}$ protein) and this band reacted with the anti-myosin antiserum (Fig. 6, lane 5).

Taken together, the blotting data show that the 40$\mathrm{kDa}$ protein binds SP-A in a $\mathrm{Ca}^{2+}$ - and mannose-dependent manner, but reacted only slightly with antiactin antiserum. The $210-\mathrm{kDa}$ protein binds SP-A in a $\mathrm{Ca}^{2+}$-dependent manner, but independent of mannose, and no cross-reaction with the anti-myosin antiserum used was found. Therefore, SP-A binding bands of either size might represent two different SP-A receptors.

\section{DISCUSSION}

In an attempt to investigate SP-A binding proteins on the surface of bovine alveolar macrophages we first characterized these cells and studied SP-A binding and uptake using two different methods. We examined binding of unlabeled SP-A with ELISA and binding of SP-A-coated gold particles in the transmission electron microscope. Uptake of SP-A into macrophages followed the coated pit/vesicle pathway. In a previous paper we had shown that gold-labeling of SP-A does not influence binding since gold-labeled SP-A revealed the same binding characteristics to alveolar macrophages as unlabeled SP-A, as visualized with the immuno-gold technique by antibody-labeled gold particles [23]. Now we can show that bovine alveolar macrophages bind human SP-A in $\mathrm{a} \mathrm{Ca}^{2+}$ - and mannose-dependent manner and that binding is specific (Table 1, Fig. 2). Since binding of SP-A to the bovine cells exhibits the same characteristics as we have already described for rat alveolar macrophages [9] this system could be used for receptor isolation from larger amounts of cell material.

In order to work with a homologous system we used bovine SP-A to isolate SP-A receptors from bovine alveolar macrophages. SP-A isolated from bovine lung revealed the expected molecular weight of $32-36 \mathrm{kDa}$. Furthermore, the bovine SP-A bound phospholipids, inhibited phorbolester-stimulated surfactant secretion of rat type II cells, and enhanced phagocytosis of $S$. aureus in rat alveolar macrophages. These tests show the functional integrity of the SP-A isolated from bovine lung lavage. For isolation of receptors, SP-A was bound to Dynabeads. As binding of SP-A to the beads occurs randomly, this procedure should reveal particlebound SP-A with all domains accessible to the receptors. SP-A Dynabeads were incubated with freshly isolated bovine alveolar macrophages. Cells were solubilized by Triton X-100, the receptor-ligand-Dyna-

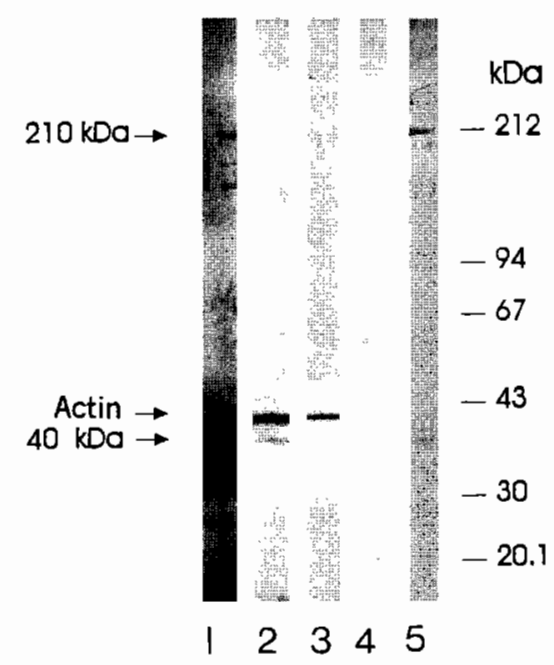

FIG. 6. Proteins of the SP-A receptor preparation in comparison to actin and myosin. SP-A receptor preparation (lanes 1, 2, 4), actin from bovine muscle (lane 3), and myosin heavy chain from rabbit muscle (lane 5) fractionated on 10\% SDS-PAGE under reducing conditions were blotted onto nitrocellulose and incubated with bovine SP-A (lane 1), with antibody against human muscle actin (lanes 2,3 ), and with antibody against bovine muscle myosin (lanes 4,5 ). Bound SP-A was detected as described in the legend to Fig. 5. Bound antibodies were detected with the respective second antibodies labeled with alkaline phosphatase. 
bead complex was separated from cell debris by magnetic force, and the SP-A binding proteins were detached from SP-A by addition of EDTA to chelate $\mathrm{Ca}^{2+}$. Following the blot analysis we suggest two proteins as putative SP-A receptors, a $40-\mathrm{kDa}$ protein and a 210 $\mathrm{kDa}$ protein. The latter bound SP-A in a $\mathrm{Ca}^{2+}$-dependent but mannose-independent way (Fig. 5) and is not recognized by the anti-myosin antiserum we tested. The $40-\mathrm{kDa}$ protein bound SP-A in a $\mathrm{Ca}^{2+}$ - and mannose-dependent fashion (Figs. 4 and 5) and could be responsible for the mannose-dependent binding of SP-A to macrophages. The slight reaction seen with anti-actin antiserum represents either a minor contamination with a $40-\mathrm{kDa}$ actin degradation product or cross-reactivity with the receptor protein.

It is under discussion which domain is responsible for SP-A binding to macrophages and to other cells of the respiratory tract. Our own studies up to now favored a lectin-mediated binding to macrophages whereby the carbohydrate recognition domain binds to a respective structure on the cell surface $[8,9]$. We could exclude participation of the mannose receptor on the macrophage surface which theoretically could recognize the glycoconjugates of the SP-A molecules [9]. Furthermore, SP-A binding was partially inhibited not only by mannan and mannosylated BSA but also by the collagenase-resistant fragment of SP-A (CRF) representing mainly the globular part of the molecular $(44 \%$ with $0.1 \mathrm{mg} / \mathrm{ml}$ CRF). Inhibition by the collagen-like fragment of $\mathrm{C} 1 \mathrm{q}$ resembling strongly the collagen-like tail of SP-A was also seen, though to a lesser extent (19\% with $0.1 \mathrm{mg} / \mathrm{ml}$ ) [23]. Taken together, our results published up to now suggested that at least part of the binding is mediated by the lectin domain of the SP-A molecule that is localized on the globular domain and could recognize glycoconjugates on the macrophages. We cannot exclude, however, participition of the collagen-like domain of SP-A in binding. These findings could indicate the existence of two SP-A receptors on macrophages which would be in agreement with the data showing different effects of SP-A on macrophages.

Chroneos et al. [13] favored the participition of the collagen-like domain in binding. They isolated a 210$\mathrm{kDa}$ receptor protein from U937 rat cells by SP-A affinity chromatography with SP-A bound to maltoseSepharose, i.e., the carbohydrate binding domains of the SP-A molecules were blocked. This procedure should preferentially yield receptors binding to the collagen-like domain of SP-A. Other authors also claimed binding via this domain and suggested binding to the $\mathrm{C} 1 \mathrm{q}$ receptor $[11,12]$. Nevertheless, Chroneos et $a l$. demonstrated that SP-A binding to macrophages was distinct from binding to the $\mathrm{C} 1 \mathrm{q}$ receptor. As they used SP-A with blocked carbohydrate binding sites as ligand for receptor preparation this potential binding mechanism was not included in their analysis.
There is also a discrepancy with regard to the involvement of the lectin domain of SP-A in binding to cells. Our data showed at least partial inhibition by mannose when we analyzed SP-A binding to human macrophages and monocytes and rat and bovine alveolar macrophages, using human SP-A from proteinosis patients or bovine SP-A. We also demonstrated the accessibility of mannose structures on the surface of alveolar macrophages by using the mannose-specific lectin concanavalin A [9]. Chroneos et al. [13] found no influence of carbohydrates on SP-A binding to rat bone marrow-derived macrophages. One reason for the differences in results could be the use of different cell types.

Binding of SP-A to defined glycoconjugates on the surfaces of some pathogenic microorganisms has been already demonstrated. Zimmerman et al. [24] described binding of SP-A to a $120-\mathrm{kDa}$ glycoprotein on Pneumocystis carinii. Recently, we demonstrated that SP-A binds to a mannose structure (containing Man $\alpha 1$ Man) on the capsule of Klebsiella pneumoniae [17].

Taken together, there are arguments for both types of binding. SP-A could bind, via the collagen-like domain as well as the lectin domain, to the surface of macrophages and to other cells. This report describes binding of SP-A to bovine alveolar macrophages partially inhibitable by mannan and dependent on $\mathrm{Ca}^{2+}$ and furthermore two proteins isolated from the macrophages with homologous SP-A which could represent two different SP-A receptors. The $210-\mathrm{kDa}$ protein could be identical with the SP-A receptor isolated by Chroneos et al. [13] which binds the collagen-like domain of SP-A in a $\mathrm{Ca}^{2+}$-dependent manner. The 40 $\mathrm{kDa}$ protein described by us could be a receptor for the carbohydrate recognition site on the globular domain of the SP-A molecule. This second receptor would bind $\mathrm{SP}-\mathrm{A}$ in a $\mathrm{Ca}^{2+}$ - and mannose-dependent manner. Further experiments are necessary to localize the binding proteins on the cell surface of the macrophages.

We thank Dr. Paul Stevens, Charité, Berlin, Germany, for help with the isolation of SP-A from bovine lung lavage. We thank Byk Gulden Pharmaceuticals (Konstanz, Germany) for financial support. This study was supported by a grant from the Deutsche Forschungsgemeinschaft (P1 78/9-2).

\section{REFERENCES}

1. Weaver, T. E., and Whitsett, J. A. (1991). Function and regulation of expression of pulmonary surfactant-associated proteins. Biochem. I. 273, 249-264.

2. Kuroki, Y., and Voelker, D. R. (1994). Pulmonary surfactant proteins. J. Biol. Chem. 269, 25943-25946.

3. Batenburg, J. J. (1995). Biosynthesis, secretion, and recycling of surfactant components. In "Lung Biology in Health and Disease" (C. Lenfant, Ed.), vol. 84, Surfactant Therapy for Lung 
Disease (B. Robertson and H. W. Taeusch, Eds.), Dekker, New York.

4. Kuroki, Y., Mason, R. J., and Voelker, D. R. (1988). Alveolar type II cells express a high-affinity receptor for pulmonary surfactant protein A. Proc. Natl. Acad. Sci. USA 85, 5566-5570.

5. Wright, J. R., Borchelt, J. D., and Hawgood, S. (1989). Lung surfactant apoprotein SP-A (26-36 kDa) binds with high affinity to isolated alveolar type II cells. Proc. Natl. Acad. Sci. USA 86, 5410-5414.

6. Kuroki, Y., McCormack, F. X., Ogasawara, Y., Mason, R. J., and Voelker, D. R. J. (1994). Epitope mapping for monoclonal antibodies identifies functional domains of pulmonary surfactant protein A that interact with lipids. Biol. Chem. 269, 2979329800.

7. McCormack, F. X., Kuroki, Y., Stewart, J. J., Mason, R. J., and Voelker, D. R. (1994). Surfactant protein A amino acids Glu ${ }^{195}$ and $\mathrm{Arg}^{197}$ are essential for receptor binding, phospholipid aggregation, regulation of secretion, and the facilitated uptake of phospholipid by type II cells. J. Biol. Chem. 269, 29801-29807.

8. Wintergerst, E., Manz-Keinke, H., Plattner, H., and SchlepperSchäfer, J. (1989). The interaction of a lung surfactant protein (SP-A) with macrophages is mannose dependent. Eur. J. Cell Biol. 50, 291-298.

9. Manz-Keinke, H., Egenhofer, C., Plattner, H., and SchlepperSchäfer, J. (1991). Specific interaction of lung surfactant protein A (SP-A) with rat alveolar macrophages. Exp. Cell Res. 192, 597-603.

10. Pison, U., Wright, J. R., and Hawgood, S. (1992). Specific binding of surfactant apoprotein SP-A to rat alveolar macrophages. Am. J. Physiol. 262, L412-L417.

11. Malhotra, R., Thiel, S., Reid, K. B. M., and Sim, R. B. J. (1990). Human leukocyte C1q receptor binds other soluble proteins with collagen domains. Exp. Med. 172, 955-959.

12. Malhotra, R., Haurum, J., Thiel, S., and Sim, R. B. (1992). Interaction of $\mathrm{C} 1 \mathrm{q}$ receptor with lung surfactant protein A. Eur. J. Immunol. 22, 1437-1445.

13. Chroneos, Z. C., Abdolrasulnia, R., Whitsett, J. A., Rice, W. R., and Sheperd, V. L. (1996). Purification of a cell-surface receptor for surfactant protein A. J. Biol. Chem. 271, 16375-16383.

14. Hawgood, S., Benson, B. J., Schilling, J., Damm, D., Clements, J. A., and White, R. T. (1987). Nucleotide and amino acid sequences of pulmonary surfactant protein SP 18 and evidence for cooperation between SP 18 and SP 28-36 in surfactant lipid adsorption. Proc. Natl. Acad. Sci. USA 84, 66-70.

15. Manz-Keinke, H., Plattner, H., and Schlepper-Schäfer, J. (1992). Lung surfactant protein A (SP-A) enhances serum-independent phagocytosis of bacteria by alveolar macrophages. Eur. J. Cell Biol. 57, 95-100.

16. Kolb-Bachofen, V., Schlepper-Schäfer, J., Vogell, W., and Kolb, H. (1982). Electron microscope evidence for an asialoglycoprotein receptor on Kupffer cells: Localization of lectin-mediated endocytosis. Cell 29, 859-866.

17. Kabha, K., Schmegner, J., Keisari, Y., Parolis, H., SchlepperSchäfer, J., and Ofek, I. (1996). SP-A enhances phagocytosis of Klebsiella by interaction with capsular polysaccharides and alveolar macrophages. Am. J. Physiol. 272, L344-L352.

18. Hawgood, S., Benson, B. J., and Hamilton, R. L. (1985). Effects of a surfactant-associated protein and calcium ions on the structure and surface activity of lung surfactant lipids. Biochemistry 24, 184-190.

19. Oosting, R. S., and Wright, J. R. (1994). Characterization of the surfactant protein A receptor: Cell and ligand specificity. Am. J. Phys. 267, L165-L172.

20. Wileman, T. E., Lennartz, M. R., and Stahl, P. D. (1986). Identification of the macrophage mannose receptor as a $175-\mathrm{kDa}$ membrane protein. Proc. Natl. Acad. Sci. USA 83, 2501-2505.

21. Laemmli, U. K. (1970). Cleavage of structural proteins during the assembly of the head of bacteriophage T4. Nature 227, 680-685.

22. Dobbs, L. G. (1987). Pulmonary surfactant and its components inhibit secretion of phosphatidylcholin from cultured rat alveolar type II cells. Proc. Natl. Acad. Sci. USA 84, 1010-1014.

23. Ohmer-Schröck, D., Schlatterer, C., Plattner, H., and Schlepper-Schäfer, J. (1993). Interaction of lung surfactant protein A (SP-A) with alveolar macrophages. Microsc. Res. Technol. 26, 374-380.

24. Zimmerman, P. E., Voelker, D. R., McCormack, F. X., Pailsrud, J. R., and Martin II, W. L. (1992). 120-kD surface glycoprotein of Pneumocystis carinii is a ligand for surfactant protein A. J. Clin. Invest. 89, 143-149. 